\title{
The bi-modal effects of estradiol on gonadotropin synthesis and secretion in female mice are dependent on estrogen receptor- $\alpha$
}

\author{
Jonathan Lindzey ${ }^{1}$, Friederike L Jayes, Mariana M Yates, John F Couse and Kenneth S Korach \\ Receptor Biology Section, Laboratory of Reproductive and Developmental Toxicology, National Institute of Environmental Health Sciences, National Institutes \\ of Health, MD B3-02, PO Box 12233, Research Triangle Park, North Carolina 27709, USA \\ ${ }^{1}$ Department of Biological Sciences, Lock Haven University, Lock Haven, Pennsylvania 17745, USA \\ (Requests for offprints should be addressed to K Korach; Email: korach@niehs.nih.gov)
}

\begin{abstract}
Depending on the estrous/menstrual cycle stage in females, ovarian-derived estradiol $\left(E_{2}\right)$ exerts either a negative or a positive effect on the hypothalamic-pituitary axis to regulate the synthesis and secretion of pituitary gonadotropins, $\mathrm{LH}$, and FSH. To study the role of estrogen receptor- $\alpha$ (ER $\alpha)$ mediating these effects, we assessed the relevant parameters in adult wild-type (WT) and ER $\alpha$-null ( $\alpha$ ERKO) female mice in vivo and in primary pituitary cell cultures. The $\alpha$ ERKO mice exhibited significantly higher plasma and pituitary LH levels relative to WT females despite possessing markedly high levels of circulating $\mathrm{E}_{2}$. In contrast, hypothalamic GnRH content and circulating FSH levels were comparable between genotypes. Ovariectomy led to increased plasma LH in WT females but no further increase in $\alpha$ ERKO females, while plasma FSH levels increased in both genotypes. $\mathrm{E}_{2}$ treatment suppressed the high plasma LH and pituitary Lhb mRNA expression in ovariectomized WT females but had no effect in $\alpha$ ERKO. In contrast, $E_{2}$ treatments only partially suppressed
\end{abstract}

plasma FSH in ovariectomized WT females, but this too was lacking in $\alpha$ ERKO females. Therefore, negative feedback on FSH is partially $\mathrm{E}_{2} / \mathrm{ER} \alpha$ mediated but more dependent on ovarian-derived inhibin, which was increased threefold above normal in $\alpha$ ERKO females. Together, these data indicate that $\mathrm{E}_{2}$-mediated negative feedback is dependent on functional $\mathrm{ER} \alpha$ and acts to primarily regulate $\mathrm{LH}$ synthesis and secretion. Studies in primary cultures of pituitary cells from WT females revealed that $\mathrm{E}_{2}$ did not suppress basal or $\mathrm{GnRH}$-induced $\mathrm{LH}$ secretion but instead enhanced the latter response, indicating that the positive influence of $\mathrm{E}_{2}$ on gonadotropin secretion may occur at the level of the pituitary. Once again this effect was lacking in $\alpha E R K O$ gonadotropes in culture. These data indicate that the aspects of negative and positive effects of $\mathrm{E}_{2}$ on gonadotropin secretion are $\mathrm{ER} \alpha$ dependent and occur at the level of the hypothalamus and pituitary respectively.

Journal of Endocrinology (2006) 191, 309-317

\section{Introduction}

Gonadotropin-releasing hormone $(\mathrm{GnRH})$ is secreted in a pulsatile pattern from the hypothalamus into the hypothalamichypophyseal portal veins that drain into the anterior pituitary, and is the primary stimulus for the synthesis and secretion of follicle-stimulating hormone (FSH) and luteinizing hormone (LH) in the latter organ (Gharib et al. 1990, Haisenleder et al. 1994, Vale et al. 1994, Shupnik 1996). However, the endocrine role of gonad-derived steroids and peptides (e.g. estradiol $\left(E_{2}\right)$ and inhibins) on the hypothalamic-pituitary (HP) axis to modulate gonadotropin synthesis and secretion is also well described and critical to reproductive function (Gharib et al. 1990, Haisenleder et al. 1994, Vale et al. 1994, Shupnik 1996). In most mammals, the estrous cycle is dictated by the bi-modal actions of ovarian-derived estrogens on the HP axis such that moderate levels of $\mathrm{E}_{2}$ during early folliculogenesis are suppressive to $\mathrm{LH}$ secretion, while an acute rise in $\mathrm{E}_{2}$ levels at proestrus acts to prime the hypothalamus and/or pituitary to produce the hallmark pre-ovulatory gonadotropin surge that induces ovulation (Freeman 1994). The mechanisms and precise sites of action by which estrogens exert both negative and positive effects on the HP axis are still under investigation. Feedback at the level of the hypothalamus is illustrated by reports that ovariectomy results in upregulation of $\mathrm{GnRH}$ and that exogenous $\mathrm{E}_{2}$ treatment of ovariectomized female rodents restores to normal the hypothalamic levels of GnRH mRNA (Zoeller \& Young 1988, Zoeller et al. 1988), GnRH content (Wise et al. 1981a), and GnRH secretion (Wise \& Ratner 1980, Wise et al. 1981b). However, in vitro studies demonstrate that some effects of $E_{2}$ on the pituitary are clearly independent of hypothalamic influence, including a suppression of $F$ shb (FSH- $\beta$ mRNA) expression (Miller \& Miller 1996; sheep) and an increase of Lhb (LH- $\beta$ mRNA) expression (Shupnik et al. $1989 a$; rat). Furthermore, such effects of $E_{2}$ on gonadotropin gene expression appear to be estrogen receptor (ER) mediated, either via estrogen-response elements within the promoter regions of the gonadotropin subunit genes (Shupnik et al. 1989b) 
or via interactions with other key transcription factors (Miller \& Miller 1996). $E_{2}$ may also directly modulate the pituitary response to $\mathrm{GnRH}$ via regulation of $\mathrm{GnRH}$-receptor $(\mathrm{GnRH}-$ R) levels (Naik et al. 1984, Turgeon et al. 1996).

Historically, a single form of nuclear ER, now known as $E R \alpha$, was thought to mediate the effects of $E_{2}$ on gonadotropin secretion. However, the discovery of a second form of nuclear ER, the ER $\beta$ (Kuiper et al. 1996, Mosselman et al. 1996, Tremblay et al. 1997), presents the possibility that two independent receptor forms may mediate the differential effects of $E_{2}$ feedback on the $\mathrm{HP}$ axis. The comparable binding affinities of $\mathrm{ER} \alpha$ and $\mathrm{ER} \beta$ for various estrogenic ligands (Kuiper et al. 1997) have hampered the development of selective agonists or antagonists that could be employed to differentiate the actions of each receptor form. Therefore, the $\mathrm{ER} \alpha$ and ER $\beta$-null ( $\alpha \mathrm{ERKO}$ and $\beta \mathrm{ERKO}$ respectively) mice provide unique models to discern the contribution of each receptor form in mediating the feedback effects of $E_{2}$ in the HP axis. ER $\alpha$-null female mice have a hypoplastic reproductive tract. They are anovulatory, invariably possess ovaries that exhibit multiple atretic and enlarged cystic follicles and hypertrophied theca (Couse \& Korach 1999). Plasma levels of gonadal steroids are significantly elevated in aERKO females compared with wild-type (WT) females (Couse et al. 2003), as are plasma LH concentrations (Couse et al. 2003), presumably due to the lack of $E_{2}$-mediated negative feedback in the HP axis of $\alpha$ ERKO females. However, plasma FSH levels are similar in $\alpha$ ERKO and WT adult female mice (Couse et al. 2003).

Both ER $\alpha$ and $E R \beta$ transcripts and immunoreactivity have been localized to hypothalamic nuclei thought to be involved in regulating GnRH secretion in rats and mice (Li et al. 1997, Shughrue et al. 1997a, Laflamme et al. 1998). Furthermore, high-affinity $\mathrm{E}_{2}$ binding and transcripts encoding $\mathrm{ER} \beta$ (Skynner et al. 1999, Hrabovszky et al. 2000), estrogenrelated receptor- $\alpha$ (ERR $\alpha$; Herbison \& Pape 2001) but not $\mathrm{ER} \alpha$ (Herbison \& Pape 2001) are reportedly present in GnRH-secreting neurons of the mouse hypothalamus; thereby, challenging the long-held hypothesis that estrogen actions in these cells are indirect. In the pituitary, both ER $\alpha$ and ER $\beta$ are expressed in the adult rat (Wilson et al. 1998), whereas adult mice may possess ER $\alpha$ only (Couse et al. 1997, Couse \& Korach 1999).

Thus, in the present study, we characterized the role of $\mathrm{ER} \alpha$ in regulating gonadotropin synthesis and secretion by evaluating and comparing the following parameters in wildtype and $\alpha$ ERKO female mice: (1) hypothalamic GnRH content, (2) circulating and pituitary gonadotropin levels, (3) effects of $E_{2}$ replacement on circulating gonadotropin levels and pituitary $L h b$ expression in ovariectomized wildtype and $\alpha E R K O$ females, and (4) secretory response of gonadotropes to $\mathrm{E}_{2}$ and $\mathrm{GnRH}$ challenges in vitro. Our results indicate that female $\alpha \mathrm{ERKO}$ mice exhibit normal hypothalamic GnRH content, increased plasma and pituitary LH levels despite excessively high levels of circulating $\mathrm{E}_{2}$, but relatively normal plasma FSH levels and low pituitary FSH levels that may be attributed to increased ovarian production of inhibin. Furthermore, ovariectomized $\alpha$ ERKO females were refractory to the negative feedback effects of exogenous $\mathrm{E}_{2}$ that effectively suppressed LH gonadotropin synthesis and secretion in WT females. Likewise, $\alpha \mathrm{ERKO}$ pituitary cells in culture were refractory to the positive effects of $E_{2}$ that effectively increased GnRH-stimulated LH release from WT pituitary cells.

\section{Materials and Methods}

\section{Animals}

All procedures involving animals were pre-approved by the National Institute of Environmental Health Sciences (NIEHS) Animal Care and Use Committee. Animals were maintained in plastic cages in a temperature-controlled room $\left(21-22^{\circ} \mathrm{C}\right)$ under a $12 \mathrm{~h}$ light: $12 \mathrm{~h}$ darkness schedule and provided with NIH 31 mouse chow and fresh water available ad libitum. WT $\left(E s r 1^{+/+}\right)$and Esr1 ${ }^{-/-}(\alpha \mathrm{ERKO})$ mice of the $\mathrm{C} 57 \mathrm{BL} / 6$ strain were obtained from our colony at Taconic Farms, Germantown, NY, USA and used at 10-16 weeks of age. All animals were genotyped by PCR on DNA extracted from tail biopsies using the Wizard SV 96 Genomic DNA extraction kit (Promega) as previously described (Couse et al. 2003). Mice were ovariectomized using isoflurane anesthesia according to NIEHS approved surgical procedures and allowed to rest 2 weeks prior to experimental use.

\section{Experimental design}

Experiment 1 Intact, adult WT and $\alpha \mathrm{ERKO}$ female mice were killed during 0900-1100 h to determine the basal levels of (1) hypothalamic GnRH content, (2) pituitary gonadotropin content, (3) plasma gonadotropin levels, and (4) serum and plasma inhibin-A levels. Due to sample limitations, not all endpoints were measured in the same group of animals. Animals were killed by $\mathrm{CO}_{2}$ asphyxiation, whole blood was immediately collected from the inferior vena cava; hypothalami and pituitaries were then immediately removed and snap-frozen, and then stored at $-70{ }^{\circ} \mathrm{C}$ until analysis. Whole blood or whole blood mixed with heparin $(60 \mathrm{mg} / \mathrm{ml})$ was centrifuged at $8000 \mathrm{~g}$ at $4{ }^{\circ} \mathrm{C}$ to collect serum or plasma respectively and stored at $-70{ }^{\circ} \mathrm{C}$ until further analysis.

Experiment 2 To examine the effect of ovariectomy and $\mathrm{E}_{2}$ replacement on plasma gonadotropin levels and pituitary gonadotropin gene expression, ovariectomized adult female WT and $\alpha$ ERKO mice were injected subcutaneously with $100 \mu \mathrm{l}$ vehicle (sesame oil) or $17 \beta-\mathrm{E}_{2}$ (Research Plus, Inc., Manasquan, NJ, USA) at $50 \mu \mathrm{g} / \mathrm{kg}$ body weight for three consecutive days between 0900 and $1100 \mathrm{~h}$. $\mathrm{E}_{2}$ treatments of $15-50 \mu \mathrm{g} / \mathrm{kg}$ per day for three consecutive days consistently induce a maximum uterotropic response in ovariectomized 
WT mice (Lubahn et al. 1993, Hewitt et al. 2003). We used the higher dose in the present studies to more closely mimic the elevated $\mathrm{E}_{2}$ levels that are endogenous to intact $\alpha \mathrm{ERKO}$ female mice (Couse et al. 2003). Blood and tissues were collected $24 \mathrm{~h}$ after the final treatment.

Experiment 3 To examine the effects of $E_{2}$ on basal and GnRH-induced LH secretion in the absence of hypothalamic influence, dispersed pituitary cell cultures were prepared from adult WT and $\alpha$ ERKO females according to the procedure of Huang et al. (2001) with the following modifications. Pituitaries were harvested and pooled according to genotype ( $n>9$ per genotype per experiment), then minced in $1 \times$ Hank's balanced salt solution (HBSS; Invitrogen) supplemented with $25 \mathrm{mM}$ HEPES (Sigma) and $0.15 \mathrm{mM}$ calcium chloride. The resulting tissue fragments were then digested in HBSS with HEPES containing Cls-2 collagenase $(640 \mathrm{U} / \mathrm{ml}$; $200 \mu \mathrm{l} / 5$ pituitaries; Worthington, Lakewood, NJ, USA) at $36.5{ }^{\circ} \mathrm{C}$ for $2-3 \mathrm{~h}$ with periodic vortexing; followed by incubation in calcium-magnesium free HBSS with HEPES containing $0 \cdot 25 \%$ pancreatin (Invitrogen) for $15-20 \mathrm{~min}$ at $36 \cdot 5{ }^{\circ} \mathrm{C}$. The dispersed cells were then vigorously vortexed, pelleted, and washed three times in culture media (DMEM without phenol red; $10 \%$ stripped fetal calf serum; with PenStrep; Invitrogen) and filtered through $50 \mu \mathrm{m}$ Nitex (Sefar Filtration, Depew, NY, USA) to remove aggregates and debris. Cells were counted and plated $\left(1.5 \times 10^{5}\right.$ cells/well; four to five wells per treatment) in 96-well plates coated with Matrigel (BD Biosciences, San Jose, CA, USA) diluted 1:3 with DMEM. Cells were incubated in a humidified chamber of $95 \% \mathrm{O}_{2}: 5 \% \mathrm{CO}_{2}$ at $37^{\circ} \mathrm{C}$. After $24 \mathrm{~h}$, the media were changed to culture media containing either vehicle (ethanol) or $\mathrm{E}_{2}(10$ and $100 \mathrm{pg} / \mathrm{ml})$. After $48 \mathrm{~h}$, the spent medium was carefully removed by aspiration and replaced with experimental medium (DMEM without phenol red; no serum; $0 \cdot 1 \% \mathrm{BSA})$ containing vehicle or $\mathrm{E}_{2}(10$ and $100 \mathrm{pg} / \mathrm{ml})$, and/or GnRH (10 nM; Sigma). The cells were allowed to incubate for an additional $2 \mathrm{~h}$, after which the media were rapidly collected and stored at $-70{ }^{\circ} \mathrm{C}$ until analysis. The cells were then processed later for RNA extraction. This experiment was repeated three times with similar results.

\section{Hormone measurements}

To measure hypothalamic GnRH content, hypothalami were collected from individual animals and frozen immediately upon animal death. An aqueous supernatant was prepared from each hypothalamus by sonicating in $0 \cdot 1 \mathrm{~N}(0 \cdot 1 \mathrm{M})$ acetic acid $(500 \mu \mathrm{l})$, boiling for $5 \mathrm{~min}$, and pelleting the cellular debris by centrifugation at $14000 \mathrm{~g}$ at $4{ }^{\circ} \mathrm{C}$. The resulting supernatant containing $\mathrm{GnRH}$ was then lyophilized overnight, resuspended in a fixed volume of RIA buffer, and then duplicate aliquots per preparation were subjected to RIA for mature GnRH as previously described (Wetsel et al. 1996). The cellular debris pellets were stored at $-70{ }^{\circ} \mathrm{C}$ and later used to determine the total protein content using the BCA assay (Bio-Rad) according to the manufacturer's protocol. Intra- and inter-assay coefficients of variation were 6 and $9 \%$ respectively.

Plasma and pituitary gonadotropin levels were assessed using rat $\mathrm{LH}$ and FSH RIAs that were previously reported to accurately measure mouse gonadotropins (Beamer et al. 1972, Darney et al. 1992). For plasma samples, $50 \mu$ l aliquots were assayed for $\mathrm{LH}$ and FSH in duplicate when sample volume allowed. To assess pituitary gonadotropin content, individual pituitaries were sonicated in $500 \mu \mathrm{l}$ RIA buffer and duplicate $5 \mu \mathrm{l}$ aliquots of a tenfold dilution of the homogenate were assayed. Individual $\mathrm{LH}$ and FSH levels below the limit of detection were assigned a value equal to the lower limit for each respective assay (FSH $1.6 \mathrm{ng} / \mathrm{ml}$; $\mathrm{LH} 0 \cdot 12 \mathrm{ng} / \mathrm{ml}$ ).

LH secretion by cultured pituitary cells was assessed using rat LH kits previously reported to accurately measure mouse LH (Couse et al. 2003; GE Healthcare Life Sciences, Piscataway, NJ, USA). Aliquots $(75 \mu \mathrm{l})$ were assayed singly. The limit of detection was $0.08 \mathrm{ng} / \mathrm{ml}$ and the intra-assay coefficient of variation was $6 \%$.

Inhibin-A levels were assessed in $50 \mu \mathrm{l}$ aliquots of serum or plasma using the active inhibin-A ELISA (Diagnostic Systems Laboratories, Webster, TX, USA) according to the manufacturer's protocol. Serum samples ( $n=12$ per genotype) were assayed in duplicate and plasma samples $(n=9-11$ per genotype) were assayed as singlets. Results did not differ between serum and plasma samples and were combined before final statistical analysis. The range of detection was $10-1000 \mathrm{pg} / \mathrm{ml}$. The inter- and intra-assay coefficients of variation were 7 and $10 \%$ respectively.

\section{RNA isolation and analysis}

Total RNA was isolated from individual snap-frozen pituitaries or pituitary cell cultures using Trizol reagent (Invitrogen) according to the manufacturer's protocol. Glycogen $(10 \mu \mathrm{g} /$ tube) was added prior to the final alcohol precipitation to maximize RNA yield. The concentration of all final preparations was calculated via an $\mathrm{A}_{260}$ reading using a Molecular Devices Spectramax (Sunnyvale, CA, USA) spectrophotometer followed by electrophoresis of a $1 \mu \mathrm{g}$ aliquot to ensure integrity prior to further analysis.

Pituitary levels of Lhb mRNA were assessed by northern blot analysis on $1 \mu \mathrm{g}$ aliquots of total RNA from individual pituitaries, then normalized by subsequent probing for $R p l 7$ mRNA as previously described (Lindzey et al. 1998). Pituitary levels of Fshb mRNA were assessed by ribonuclease protection assays (RPAs) on $1 \mu \mathrm{g}$ aliquots of total RNA from individual pituitaries, and included a probe for Ppia (cyclophilin) to normalize among samples, as previously described (Couse et al. 2003).

Gene expression in total RNA from cultured pituitary cells was assessed by quantitative real-time reverse-transcriptase PCR (qRT-PCR). For each sample (each well), cDNA was generated from $1 \mu \mathrm{g}$ RNA in a $25 \mu \mathrm{l}$ reaction mixture using random hexamers and the superscript cDNA synthesis system (Invitrogen) according to the manufacturer's protocol. Applied 
Biosystems Primer Express (Foster City, CA, USA) software was used to select primers specific for the amplification of murine gonadotropin-releasing hormone receptor (Gnrhr), common $\boldsymbol{\alpha}$-glycoprotein (Cga), Lhb, and Fshb cDNAs (Table 1). All primer sets were designed to lie in separate exons to avoid erroneous amplification of contaminating genomic DNA and confirmed to amplify a single product of the expected size via dissociation analysis and gel electrophoresis. Each sample was assayed in duplicate using the equivalent of $0 \cdot 1 \mu \mathrm{l} \mathrm{cDNA}$ (prepared as described previously), $20 \mathrm{pmol}$ of each primer and $1 \times$ SYBR Green Master Mix (Applied Biosystems) in a total reaction volume of $50 \mu \mathrm{l}$. For normalization purposes, an identical set of reactions was prepared using primers specific for Rpl7 as previously described (Hewitt et al. 2003; Table 1). Amplification was carried out in an ABI PRISM 7700 Sequence Detection System (Applied Biosystems) as follows: $50{ }^{\circ} \mathrm{C} /$ $2 \mathrm{~min}, 95^{\circ} \mathrm{C} / 10 \mathrm{~min}(1 \times)$; $95^{\circ} \mathrm{C} / 15 \mathrm{~s}, 60^{\circ} \mathrm{C} / 30 \mathrm{~s}(40 \times)$. Quantitative differences in the cDNA target between samples were determined using the mathematical model of Pfaffl (2001), in which an expression ratio was determined for each sample by calculating $\left(E_{\text {target }}\right)^{\Delta \mathrm{Ct}(\text { target })} /\left(E_{R p l 7}\right)^{\Delta \mathrm{Ct}(R p l 7)}$, where $E$ is the efficiency of a primer set and $\Delta \mathrm{Ct}=\mathrm{Ct}_{\text {(calibrator sample) }}-$ $\mathrm{Ct}_{\text {(experimental }}$ sample) and calibrator sample $=$ 'control' $=\mathrm{WT}$ noGnRH noE ${ }_{2}$. The amplification efficiency of each primer set was calculated from the slope of a standard amplification curve of $\log \mu \mathrm{cDNA}$ vs Ct value over at least four orders of magnitude $\left(E=10^{-(1 / \text { slope })}\right)$.

\section{Statistical analysis}

All data were analyzed using Levene's test for homogeneity of variance. If significant heteroscedascity was observed, data were $\log$ transformed prior to statistical analyses. Data were initially analyzed using a two-way ANOVA and the Bonferroni-Dunn post hoc test. If significant genotype and treatment interactive effects were noted, data for each genotype were analyzed separately using a one-way ANOVA and the Bonferroni-Dunn post hoc test or by $t$-tests. In addition, some comparisons between intact WT and $\alpha$ ERKO females were made using one-tail, unpaired $t$-tests. In all cases, statistical significance was accepted at $P<0 \cdot 05$.

\section{Results}

Experiment I: evaluation of reproductive hormone levels in intact $W T$ and $\alpha E R K O$ females

Despite possessing comparable levels of hypothalamic GnRH content (Fig. 1A), $\alpha$ ERKO females exhibited conspicuous dysregulation of gonadotropin synthesis and secretion in the pituitary compared with WT females (Fig. $1 \mathrm{~B}$ and $\mathrm{C}$ ). Pituitary LH content and plasma LH levels were both increased $2 \cdot 7-(P<0 \cdot 05)$ and 8 -fold $(P<0 \cdot 05)$ respectively, in $\alpha$ ERKO females relative to wild type (Fig. 1C). In contrast, plasma FSH levels did not differ between genotypes, but the average pituitary FSH content in $\alpha$ ERKO females was $50 \%$ below that of WT females $(P<$ $0 \cdot 05)$. Inhibin-A levels in $\alpha E R K O$ females were dramatically increased $(3 \cdot 7$-fold; $P<0 \cdot 05)$ compared with WT females (Fig. 1D)

Experiment II: effect of ovariectomy and $E_{2}$ treatment on the $\alpha E R K O H P$ axis in vivo

As expected, ovariectomy led to plasma FSH and LH levels that were increased almost 4- and 12-fold respectively in WT females (Figs 1 and 2). Ovariectomized $\alpha$ ERKO females exhibited similar increases in plasma FSH but showed no further rise in plasma LH levels compared with intact aERKO females (Figs 1 and 2). In ovariectomized WT females, $E_{2}$ treatments suppressed plasma LH levels to presurgery levels but decreased the heightened plasma FSH levels by only $30 \%$ (compare Figs 1 and 2). In contrast, $E_{2}$ treatments of ovariectomized $\alpha$ ERKO females failed to suppress plasma LH and FSH levels.

The effects of ovariectomy and $\mathrm{E}_{2}$ replacement on plasma gonadotropin levels in each respective genotype were mirrored by changes in $L h b$ expression in the pituitary. As previously reported, intact $\alpha$ ERKO females possess significantly increased levels of $L h b$ expression in the pituitary (Couse et al. 2003). As shown in Fig. 2, ovariectomy abolished the genotypic difference in Lhb expression. However, while WT females exhibited a $33 \%(P<0 \cdot 05)$ reduction in $L h b \mathrm{mRNAs}$ following exogenous $\mathrm{E}_{2}$ treatment, $\alpha$ ERKO females exhibited no such change.

Table 1 Primers used for RT-PCR

\begin{tabular}{|c|c|c|c|c|}
\hline & Accession no. & $\begin{array}{l}\text { Amplified } \\
\text { sequences (bp) }\end{array}$ & Forward $\left(5^{\prime}-3^{\prime}\right)$ & Reverse $\left(5^{\prime}-3^{\prime}\right)$ \\
\hline \multicolumn{5}{|l|}{ Gene } \\
\hline Fshb & NM 008045 & $28-153$ & GACTGCACAGGACGTAGCTGTTTA & CTGAGATGGTGATGTTGGTCAATT \\
\hline Gnrhr & NM 010323 & $767-866$ & TTCATCAAGACCCACGCAAA & GAGGTAGCGAATGCGACTGTC \\
\hline Lhb & NM 008497 & $100-204$ & TGTCAACGCAACTCTGGCC & GGCAGTACTCGGACCATGCT \\
\hline Rpl7 & NM 011291 & $416-436$ & AGCTGGCCTTTGTCATCAGAA & GACGAAGGAGCTGCAGAACCT \\
\hline
\end{tabular}


Experiment III: effect of $E_{2}$ treatment on $W T$ and $\alpha E R K O$ pituitary cells in vitro

To examine any direct effects that $\mathrm{E}_{2}$ may have on gonadotrope function, basal and GnRH-induced LH secretions were evaluated in primary pituitary cell cultures from WT and $\alpha$ ERKO females. Cells were first exposed to either vehicle or $\mathrm{E}_{2}(10$ or $100 \mathrm{pg} / \mathrm{ml})$ for $48 \mathrm{~h}$ and then subjected to an acute $(2 \mathrm{~h})$ challenge with GnRH in the continued presence or absence of $E_{2}$. Interestingly, $\alpha E R K O$ pituitary cells exhibited increased basal $L h b$ expression and LH secretion relative to WT cells following $48 \mathrm{~h}$ in culture, regardless of the presence or dose of $E_{2}$ (Fig. 3). Upon GnRH stimulation, non-estrogen exposed WT pituitary cells exhibited a 13-fold increase in LH secretion $(P<0 \cdot 05)$, and this was further enhanced to $>20-$ fold in WT cells when pretreated with 10 or $100 \mathrm{pg} \mathrm{E}_{2} / \mathrm{ml}$ $\left(P<0 \cdot 05\right.$ versus no $\mathrm{E}_{2}$; Fig. 3$) . \alpha \mathrm{ERKO}$ pituitary cells also exhibited increased LH secretion (two- to fourfold, depending on $\mathrm{E}_{2}$ dose) when challenged with $\mathrm{GnRH}$; however, prior $\mathrm{E}_{2}$ exposure had no enhancing effect (Fig. 3). The GnRH stimulated LH-secretory response from $\alpha \mathrm{ERKO}$ pituitary cells, when expressed as fold increase over basal LH secretion, was blunted in comparison with the WT response. However, the absolute GnRH-stimulated LH secretory response reached similar levels in $\alpha$ ERKO $(21.3 \pm 0.8 \mathrm{ng} / \mathrm{ml})$ and WT pituitary cells $(20 \cdot 4 \pm 0 \cdot 2 \mathrm{ng} / \mathrm{ml})$. In contrast to the effect of GnRH on LH secretion, no parallel increase in Lhb expression was observed in either genotype (Fig. 3). Similar assays for Cga, Fshb, and Gnrhr expression indicated no significant genotypic or treatment effects (data not shown).
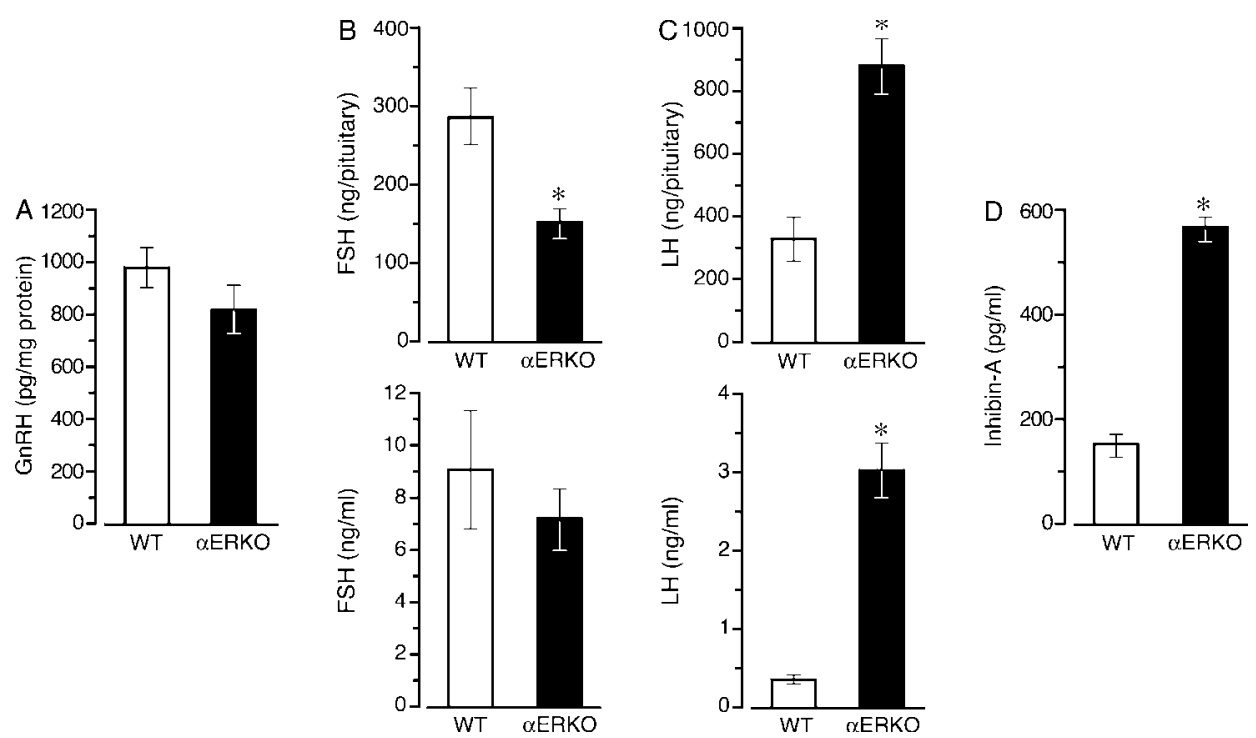

The endocrine actions of ovarian-derived $\mathrm{E}_{2}$ on the $\mathrm{HP}$ axis are vital to gonadal function and fertility in female mammals. The presence of both known ER forms in the hypothalamus and pituitary, however, confounds our abilities to discern the precise site of such actions and the contribution of each receptor form in mediating the estrogenic effects. We contend that this obstacle may be largely overcome by the study of $\alpha$ ERKO mice. Since these animals lack functional ER $\alpha$ but maintain normal ER $\beta$ expression (Couse et al. 1997), they are especially suited to reveal phenotypes that may distinguish the actions of the two ERs. Herein, we have employed $\alpha$ ERKO female mice to demonstrate that $E R \alpha$ functions are fundamental to the negative-feedback actions of $E_{2}$ in the $\mathrm{HP}$ axis, congruent with earlier reports (Wersinger et al. 1999, Couse \& Korach 1999, Couse et al. 1999, 2003). Furthermore, our studies indicate that ER $\alpha$-mediated actions are critical to the negative modulation of LH secretion, while FSH secretion is only partially mitigated by $\mathrm{ER} \alpha-\mathrm{E}_{2}$ actions and are more effectively regulated by ovarian-derived inhibin. We have also found evidence that ER $\alpha$-mediated actions are important for the positive modulation of $\mathrm{LH}$ secretion at the pituitary, where $\mathrm{E}_{2}$ effectively increased GnRH-stimulated LH release.

The elevated pituitary and plasma LH levels consistently found in $\alpha$ ERKO females are demonstrative of the critical role for $\mathrm{ER} \alpha$ in negatively regulating $\mathrm{LH}$ synthesis and secretion. WT females exhibited comparable increases in plasma LH only after being rid of circulating sex steroids via

Figure 1 Reproductive hormone levels in the plasma of intact wild-type (WT) and $\alpha$ ERKO females. Shown are the levels (mean \pm s.E.M.) of (A) hypothalamic gonadotropin-releasing hormone $(\mathrm{GnRH})$ content, $(\mathrm{B})$ pituitary (top) and plasma (bottom) follicle-stimulating hormone (FSH) levels, (C) pituitary (top) and plasma (bottom) luteinizing hormone (LH) levels, and (D) circulating inhibin-A levels. Statistically significant differences between genotypes were determined by Student's $t$-test $(P<0 \cdot 05)$ and are indicated by an asterisk. Sample sizes equaled 7-10 per genotype for the data shown in $(A)-(C)$, and $\geq 21$ per genotype for the data shown in (D). 


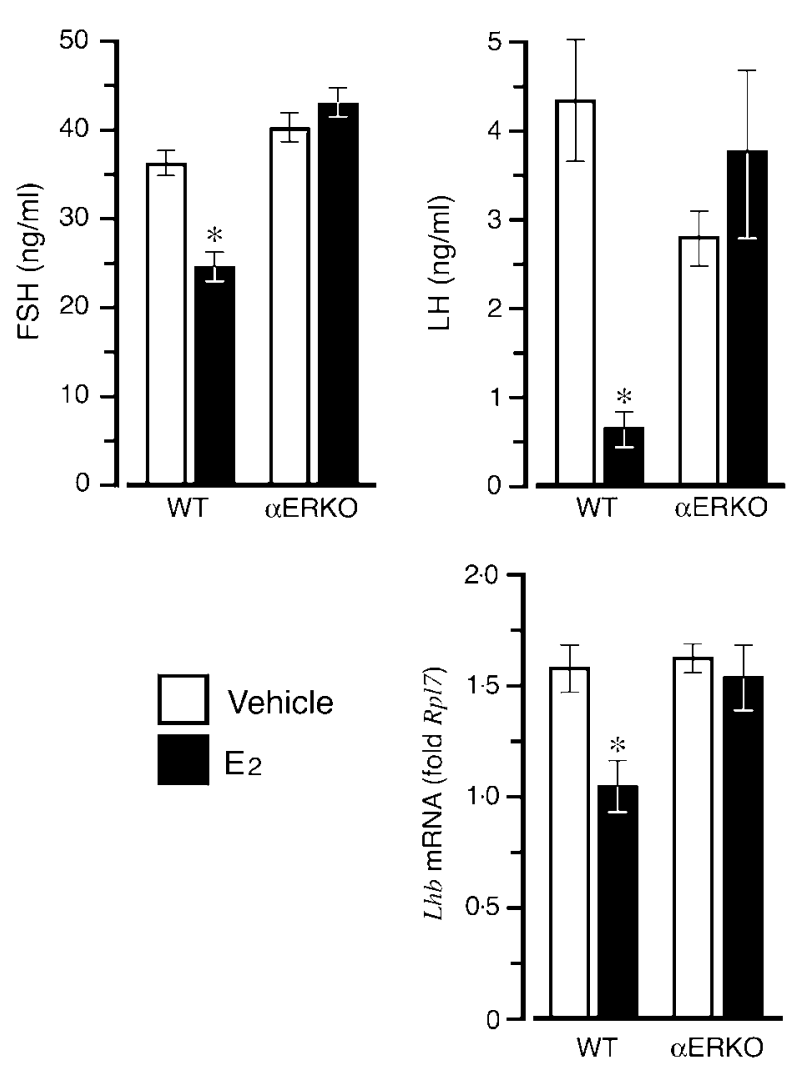

Figure 2 Pituitary gonadotropin gene expression and plasma gonadotropin levels in ovariectomized and estradiol-treated $\left(E_{2}\right)$ female mice. Shown are the levels (mean \pm S.E.M.) of plasma folliclestimulating hormone (FSH) (left) and plasma luteinizing hormone $(\mathrm{LH})$ and pituitary $L h b \mathrm{mRNA}$ (right) in ovariectomized wild-type (WT) and $\alpha$ ERKO females following treatment with either vehicle (sesame oil) or $\mathrm{E}_{2}$ (50 $\mu \mathrm{g} / \mathrm{kg}$ body weight, once per day for 3 days). $L h b$ mRNA levels were determined by northern blot and normalized to levels of Rp/7 mRNA per sample; sample sizes were seven to eight animals per group. Statistical differences between genotypes and treatments, as indicated by *, were determined by first employing a two-way ANOVA $(P<0 \cdot 05)$, followed by the Bonferroni-Dunn post hoc test $(P<0 \cdot 05$ vs vehicle-treated WT) where appropriate.

ovariectomy. Similarly, female mice devoid of endogenous $\mathrm{E}_{2}$ due to targeted disruption of the Cyp19 ( $\left.4450_{\text {aromatase }}\right)$ gene also exhibit increased plasma $\mathrm{LH}$, and this is abated upon exogenous $\mathrm{E}_{2}$ treatments (Britt et al. 2004). aERKO females consistently possess increased $\mathrm{LH}$ levels despite possessing excessively high levels of circulating $\mathrm{E}_{2}$ (Couse et al. 2003) and normal ER $\beta$ expression (Couse et al. 1997). Furthermore, ER $\beta$-null ( $\beta E R K O)$ females exhibit normal plasma LH levels (Couse et al. 2003). These data collectively indicate that $E_{2}$-mediated negative feedback on the HP axis is an $E R \alpha$-specific action and that any role of $E R \beta$ is minimal.

In contrast to LH, FSH synthesis and secretion were not increased in intact $\alpha E R K O$ females. As ovariectomy resulted in large increases in circulating FSH in both genotypes, an ovarian factor(s) is obviously required to maintain normal FSH synthesis and secretion, and this factor is also present in the $\alpha E R K O . E_{2}$ and inhibins are the two primary ovarian-derived hormones that feedback upon the female HP axis to negatively modulate gonadotropin secretion. We have previously reported that $\alpha E R K O$ females possess plasma $\mathrm{E}_{2}$ levels that are elevated almost eightfold above those of WT females ( $320 \pm 17$ vs $40 \pm 3 \mathrm{pg} / \mathrm{ml}$; Couse et al. 2003). Interestingly, $\mathrm{E}_{2}$ treatments only partially suppressed (30\%) FSH levels in ovariectomized WT females. Thus, unlike the regulation of LH secretion, $E_{2}$ may only play a minor role within the HP axis in negatively regulating FSH secretion, and this effect is mediated by ER $\alpha$ and not ER $\beta$, as $\mathrm{E}_{2}$ treatments of $\alpha \mathrm{ERKO}$ females completely failed to suppress FSH levels. Congruent with the above findings, the regulation of FSH synthesis and secretion is known to be more dependent on the inhibin/ activin family of peptide hormones (Woodruff \& Mather 1995, Gregory \& Kaiser 2004). Therefore, the reason that FSH levels are not elevated in $\alpha$ ERKO females is probably due to their plasma inhibin-A levels, which were threefold above normal. Circulating inhibin-A is primarily derived from the granulosa cells of large, pre-ovulatory follicles in the ovary (Rajkovic et al. 2006). Therefore, increased circulating inhibin-A in $\alpha$ ERKO females is not unexpected given that these animals are anovulatory and exhibit ovaries that consistently possess multiple differentiated, albeit unhealthy, follicles (Couse \& Korach 1999). Additional markers also considered to be indicative of pre-ovulatory follicles, such as $E_{2}$ synthesis (Couse et al. 2003) and LH receptor (Couse \& Korach 1999), are also increased in $\alpha E R K O$ ovaries. Interestingly, female CYP19-null mice share several aspects of the $\alpha$ ERKO ovarian phenotype but exhibit a greater than eightfold decrease in inhibin-A levels compared with WT females (Britt et al. 2005) and, accordingly, possess severely elevated levels of plasma FSH (Fisher et al. 1998). Therefore, the once perplexing difference in plasma FSH levels between $\alpha$ ERKO and CYP19-null mice is due to a drastic disparity in circulating inhibin-A levels. These data suggest that ligand-dependent actions of ER $\beta$ in granulosa cells may facilitate inhibin synthesis in the ovary by promoting granulosa cell growth and function.

The precise site of $E R \alpha$-mediated negative feedback on gonadotropin synthesis and secretion may be inferred by our findings that basal LH secretion by cultured pituitary cells from either genotype was not altered by $E_{2}$. This absence of direct $E_{2}$ effects on gonadotrope behavior strongly suggests that $\mathrm{E}_{2} / \mathrm{ER} \alpha$-mediated negative feedback occurs at the level of the hypothalamus. Other studies also indicate that $E_{2}$ negatively modulates gonadotropin secretion by decreasing the frequency of hypothalamic GnRH pulses (Sarkar \& Fink 1980 , Weick \& Noh 1984). The loss of ER $\alpha$-mediated $E_{2}$ actions leading to increased frequency of $\mathrm{GnRH}$ secretion may also lead to increased GnRH synthesis, resulting in unaltered net hypothalamic GnRH content, congruent with our observation that $\alpha$ ERKO females exhibited hypothalamic GnRH content levels that were not different from wild type.

Despite the above findings, ER $\boldsymbol{\alpha}$-null gonadotropes placed in culture and therefore removed from any hypothalamic influence 
continue to exhibit increased basal LH secretion and Lhb expression relative to WT gonadotropes. A difference in the gonadotrope population between WT and $\alpha$ ERKO pituitaries is an unlikely explanation for the increased in vitro basal $\mathrm{LH}$ secretion in the latter. In fact, female $\alpha E R K O$ pituitaries do not exhibit an increased number of gonadotropes (Scully et al. 1997) and are slightly decreased in weight (data not shown). Furthermore, our finding that other relevant gonadotrope mRNAs, such as Cga, Fshb, or Gnrhr, were not similarly increased in cultured $\alpha E R K O$ pituitary cells supports the existence of a comparable gonadotrope population in $\alpha$ ERKO pituitaries. Expression of other regulators known to be involved in gonadotrope function and regulation, such as Nr5a1 (SF-1), Egr-1, or NrOb1 (DAX-1; Achermann \& Jameson 1999) may also be altered and may contribute to the abnormally high $\mathrm{LH}$ synthesis and secretion in the $\alpha E R K O$. The preservation of abnormally high LH synthesis and secretion by ER $\alpha$-null pituitary cells, even when removed from hypothalamic influence, may be due to lingering effects of chronic GnRH hyperstimulation of the $\alpha E R K O$ pituitary prior to tissue collection. Indeed, $L h b$ mRNA levels are reported to remain stable for several days following GnRH blockade in male rats (Paul et al. 1990). Alternatively, abnormal LH secretion and Lhb expression in $\alpha \mathrm{ERKO}$ gonadotropes could be attributed to aberrant development of the anterior pituitary due to the absence of ER $\alpha$.

In contrast to the negative effects of $\mathrm{E}_{2} / \mathrm{ER} \alpha$ actions on $\mathrm{LH}$ secretion that occurs primarily via the hypothalamus, our in vitro studies indicated that $\mathrm{E}_{2}$ had a positive effect at the level of the pituitary. $E_{2}$ enhanced GnRH-induced $\mathrm{LH}$ secretion in cultured pituitary cells from WT mice. $\mathrm{E}_{2}$ priming before GnRH stimulation did not lead to similar increases in Cga, Fshb (data not shown), or Lhb expression in cells from either genotype, indicating that this is primarily a secretory response. Gnrhr expression in these cultures was also unaltered (data not shown), but our analyses are limited to the transcriptional levels and may not reflect true GnRH-R protein levels or even the level of active receptor on the gonadotrope cell surface.

However, $\mathrm{E}_{2}$ treatment of $\alpha \mathrm{ERKO}$-derived pituitary cells failed to enhance LH-secretory responses to $\mathrm{GnRH}$, indicating that this positive effect of $\mathrm{E}_{2}$ on $\mathrm{LH}$ secretion is also dependent on the presence of functional ER $\alpha$. The fact that in our cultures, the absolute amount $(\mathrm{ng} / \mathrm{ml})$ of $\mathrm{LH}$ released in response to a GnRH stimulus was not greater in $\alpha$ ERKO than in WT pituitary cells suggests that the elevated levels of plasma LH consistently present in $\alpha$ ERKO females stem from high hypothalamic GnRH secretion and not from increased pituitary responsiveness.

An attractive experimental use of $\alpha E R K O$ mice is to explore $\mathrm{E}_{2}$-mediated actions within the $\mathrm{HP}$ axis that may be independent of ER $\alpha$. For example, we have previously reported that $E s r 2(E R \beta)$ expression in the hypothalamus and pituitary of $\alpha E R K O$ females is not different from wild type (Couse et al. 1997, Couse \& Korach 1999), and therefore any role of $E R \beta$ in mediating $E_{2}$ actions is presumably intact. The possible involvement of ER $\beta$ allows for the intriguing prospect that the bi-modal feedback effects of $E_{2}$ on gonadotropin regulation are via a dual-receptor system. However, the present study produced no evidence that $\mathrm{ER} \beta$ is involved in mediating the positive feedback actions of $\mathrm{E}_{2}$ at the pituitary. Indeed, female $\beta E R K O$ mice are able to spontaneously ovulate and therefore presumably capable of producing a gonadotropin surge at proestrus (Couse \& Korach 1999), but they also exhibit reduced fecundity that
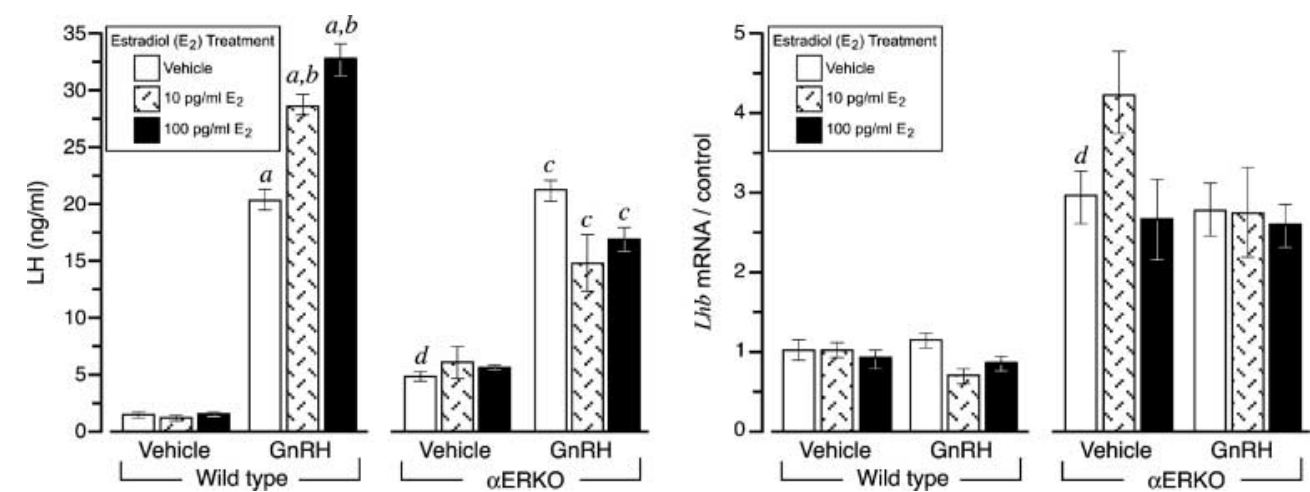

Figure 3 Evaluation of $L h b$ expression and LH secretion by wild-type and $\alpha$ ERKO pituitary cells dispersed in culture. Dispersed pituitary cells were cultured at $1 \cdot 5 \times 10^{5}$ cells per sample and exposed to vehicle (open) or estradiol $E_{2}$ at $10 \mathrm{pg} / \mathrm{ml}$ (cross-hatched) or $100 \mathrm{pg} / \mathrm{ml}$ (filled bar) for $48 \mathrm{~h}$. The cells were then challenged with vehicle or $\mathrm{GnRH}(10 \mathrm{nM})$, while maintaining the prior $E_{2}$ treatments. The medium and cells were removed after $2 \mathrm{~h}$ and assayed for LH concentration and Lhb mRNA levels respectively, as described in Materials and Methods ('control' $=$ WT noGnRH noE 2 ). Shown are means \pm s.E.M. from a representative experiment $(n=$ four to five wells per treatment). Statistical differences between genotypes and treatments were determined by first employing a two-way ANOVA that detected significant interactive effects. Data for each genotype were subsequently analyzed using a one-way ANOVA $(P<0 \cdot 05)$, followed by the Bonferroni post hoc test when appropriate. The indicated statistical differences are as follows: (a) $P<0.05$ vs wild-type groups without $\mathrm{GnRH}$; (b) $P<0.05$ vs wild type $+0.00 \mathrm{pg} / \mathrm{ml} \mathrm{E}_{2}+\mathrm{GnRH}$; (c) $P<0.05$ vs $\alpha$ ERKO groups without $\mathrm{GnRH}$; and (d) $P<0 \cdot 05$ vs wild type $+0 \cdot 00 \mathrm{pg} / \mathrm{ml} \mathrm{E}_{2}$. 
may be attributed to infrequent and/or blunted LH surges. ER $\beta$ has been postulated to facilitate the LH surge by mediating an estrogen-induced increase in progesterone receptor (PR) expression in the hypothalamus, which is required for the LH surge (Chappell et al. 1997, Chappell \& Levine 2000). This is supported by the preservation of $\mathrm{E}_{2^{-}}$ induced PR expression in the hypothalami of $\alpha \mathrm{ERKO}$ females (Shughrue et al. 1997b, Moffatt et al. 1998). In addition, $\operatorname{ER} \alpha$ and $\operatorname{ER} \beta$ transcripts are detected in an immortalized GnRH neuronal cell line (Butler et al. 1999, Roy et al. 1999), while ER $\beta$ but not ER $\alpha$ transcripts are reportedly present in GnRH-secreting neurons within the medial preoptic area of female rats (Hrabovszky et al. 2000).

In summary, our data indicate that $\mathrm{E}_{2} / \mathrm{ER} \alpha$ actions are critical to the negative modulation of LH synthesis and secretion, but less important to the regulation of FSH synthesis and secretion in female mice, and both of these actions occur primarily at the level of the hypothalamus. Conversely, the ability of $\mathrm{E}_{2}$ to enhance the $\mathrm{GnRH}$ response of wild type, but not $\alpha \mathrm{ERKO}$ gonadotropes in culture indicates that the positive influence of $\mathrm{E}_{2}$ on gonadotropin secretion is also ER $\alpha$ mediated, but occurs at the level of the pituitary. Thus, ER $\alpha$ is responsible for aspects of both negative and positive feedback effects of $E_{2}$ on LH synthesis and secretion.

\section{Acknowledgements}

The authors would like to thank Drs William Wetsel and Ralph Cooper for their assistance with $\mathrm{GnRH}$ and gonadotropin assays respectively.

\section{Funding}

J L was supported by The National Institute of Environmental Health Sciences Summers of Discovery Research Program, while conducting portions of this work. This work was supported by the Intramural Research Program of the National Institutes of Health (NIH) and National Institute of Environmental Health Sciences (NIEHS). The authors declare that there is no conflict of interest that would prejudice the impartiality of this scientific work.

\section{References}

Achermann JC \& Jameson JL 1999 Fertility and infertility: genetic contributions from the hypothalamic-pituitary-gonadal axis. Molecular Endocrinology 13 812-818.

Beamer W, Murr S \& Geschwind I 1972 Radioimmunoassay of mouse luteinizing and follicle stimulating hormone. Endocrinology 90 823-827.

Britt KL, Stanton PG, Misso M, Simpson ER \& Findlay JK 2004 The effects of estrogen on the expression of genes underlying the differentiation of somatic cells in the murine gonad. Endocrinology 145 3950-3960.
Britt KL, Simpson ER \& Findlay JK 2005 Effects of phytoestrogens on the ovarian and pituitary phenotypes of estrogen-deficient female aromatase knockout mice. Menopause 12 174-185.

Butler JA, Sjoberg M \& Coen CW 1999 Evidence for oestrogen receptor alpha-immunoreactivity in gonadotrophin-releasing hormone-expressing neurones. Journal of Neuroendocrinology 11 331-335.

Chappell PE \& Levine JE 2000 Stimulation of gonadotropin-releasing hormone surges by estrogen. I. Role of hypothalamic progesterone receptors. Endocrinology 141 1477-1485.

Chappell PE, Lydon JP, Conneely OM, O’Malley BW \& Levine JE 1997 Endocrine effects in mice carrying null mutation for the progesterone receptor gene. Endocrinology 138 4147-4152.

Couse JF \& Korach KS 1999 Estrogen receptor null mice: what have we learned and where will they lead us? Endocrine Reviews $20358-417$.

Couse JF, Lindzey J, Grandien K, Gustafsson JA \& Korach KS 1997 Tissue distribution and quantitative analysis of estrogen receptor- $\alpha(\mathrm{ER} \alpha)$ and estrogen receptor- $\beta(E R \beta)$ messenger ribonucleic acid in the wild-type and ER $\alpha$-knockout mouse. Endocrinology 138 4613-4621.

Couse JF, Bunch DO, Lindzey J, Schomberg DW \& Korach KS 1999 Prevention of the polycystic ovarian phenotype and characterization of ovulatory capacity in the estrogen receptor- $\alpha$ knockout mouse. Endocrinology 140 5855-5865.

Couse JF, Yates MM, Walker VR \& Korach KS 2003 Characterization of the hypothalamic-pituitary-gonadal axis in estrogen receptor (ER) null mice reveals hypergonadism and endocrine sex reversal in females lacking ER $\alpha$ but not ER $\beta$. Molecular Endocrinology 17 1039-1053.

Darney K, Goldman J \& Vandenburgh J 1992 Neuroendocrine responses to social regulation of puberty in the female mouse. Neuroendocrinology $\mathbf{5 5}$ 434-443.

Fisher CR, Graves KH, Parlow AF \& Simpson ER 1998 Characterization of mice deficient in aromatase (ArKO) because of targeted disruption of the Cyp19 gene. PNAS 95 6965-6970.

Freeman ME 1994 The ovarian cycle of the rat. In The Physiology of Reproduction, 2nd edn, pp 1893-1928. Eds E Knobil \& J D Neill. New York: Raven Press.

Gharib SD, Wierman ME, Shupnik MA \& Chin WW 1990 Molecular biology of the pituitary gonadotropins. Endocrine Reviews 11 177-199.

Gregory SJ \& Kaiser UB 2004 Regulation of gonadotropins by inhibin and activin. Seminars in Reproductive Medicine 22 253-267.

Haisenleder DJ, Dalkin AC \& Marshall JC 1994 Regulation of gonadotropin gene expression. In The Physiology of Reproduction, 2nd edn, pp 1793-1813. Eds E Knobil \& J D Neill. New York: Raven Press.

Herbison AE \& Pape JR 2001 New evidence for estrogen receptors in gonadotropin-releasing hormone neurons. Frontiers in Neuroendocrinology 22 292-308.

Hewitt SC, Deroo BJ, Hansen K, Collins J, Grissom S, Afshari CA \& Korach KS 2003 Estrogen receptor-dependent genomic responses in the uterus mirror the biphasic physiological response to estrogen. Molecular Endocrinology 17 2070-2083.

Hrabovszky E, Shughrue PJ, Merchenthaler I, Hajszan T, Carpenter CD, Liposits Z \& Petersen SL 2000 Detection of estrogen receptor-beta messenger ribonucleic acid and ${ }^{125}$ I-estrogen binding sites in luteinizing hormone-releasing hormone neurons of the rat brain. Endocrinology 141 3506-3509.

Huang HJ, Sebastian J, Strahl BD, Wu JC \& Miller WL 2001 The promoter for the ovine follicle-stimulating hormone-beta gene $(F S H \beta)$ confers FSH $\beta$ like expression on luciferase in transgenic mice: regulatory studies in vivo and in vitro. Endocrinology 142 2260-2266.

Kuiper GG, Enmark E, Pelto-Huikko M, Nilsson S \& Gustafsson JA 1996 Cloning of a novel receptor expressed in rat prostate and ovary. PNAS 93 5925-5930.

Kuiper GG, Carlsson B, Grandien K, Enmark E, Haggblad J, Nilsson S \& Gustafsson JA 1997 Comparison of the ligand binding specificity and transcript tissue distribution of estrogen receptors alpha and beta. Endocrinology 138 863-870. 
Laflamme N, Nappi RE, Drolet G, Labrie C \& Rivest S 1998 Expression and neuropeptidergic characterization of estrogen receptors $(E R \alpha$ and $E R \beta)$ throughout the rat brain: anatomical evidence of distinct roles of each subtype. Journal of Neurobiology 36 357-378.

Li X, Schwartz PE \& Rissman EF 1997 Distribution of estrogen receptor- $\beta$ like immunoreactivity in rat forebrain. Neuroendocrinology 66 63-67.

Lindzey J, Wetsel WC, Couse JF, Stoker T, Cooper R \& Korach KS 1998 Effects of castration and chronic steroid treatments on hypothalamic gonadotropin-releasing hormone content and pituitary gonadotropins in male wild-type and estrogen receptor- $\alpha$ knockout mice. Endocrinology 139 4092-4101.

Lubahn DB, Moyer JS, Golding TS, Couse JF, Korach KS \& Smithies O 1993 Alteration of reproductive function but not prenatal sexual development after insertional disruption of the mouse estrogen receptor gene. PNAS $9011162-11166$.

Miller CD \& Miller WL 1996 Transcriptional repression of the ovine folliclestimulating hormone-beta gene by 17 beta-estradiol. Endocrinology 137 3437-3446.

Moffatt CA, Rissman EF, Shupnik MA \& Blaustein JD 1998 Induction of progestin receptors by estradiol in the forebrain of estrogen receptor- $\alpha$ gene-disrupted mice. Journal of Neuroscience 18 9556-9563.

Mosselman S, Polman J \& Dijkema R 1996 ER $\beta$ : identification and characterization of a novel human estrogen receptor. FEBS Letters 392 49-53.

Naik SI, Young LS, Charlton HM \& Clayton RN 1984 Pituitary gonadotropin-releasing hormone receptor regulation in mice. II: females. Endocrinology 115 114-120.

Paul SJ, Ortolano GA, Haisenleder DJ, Stewart JM, Shupnik MA \& Marshall JC 1990 Gonadotropin subunit messenger RNA concentrations after blockade of gonadotropin-releasing hormone action: testosterone selectively increases follicle-stimulating hormone beta-subunit messenger RNA by posttranscriptional mechanisms. Molecular Endocrinology 4 1943-1955.

Pfaffl MW 2001 A new mathematical model for relative quantification in realtime RT-PCR. Nucleic Acids Research 29 2003-2007.

Rajkovic A, Pangas SA \& Matzuk MM 2006 Follicular development: mouse, sheep, and human models. In Knobil and Neill's Physiology of Reproduction, 3rd edn, Eds JD Neill \& E Knobil. San Diego, CA, USA: Elsevier Science.

Roy D, Angelini NL \& Belsham DD 1999 Estrogen directly represses gonadotropin-releasing hormone $(\mathrm{GnRH})$ gene expression in estrogen receptor-alpha $(\mathrm{ER} \alpha)$ - and ER $\beta$-expressing GT1-7 GnRH neurons. Endocrinology 140 5045-5053.

Sarkar DK \& Fink G 1980 Luteinizing hormone-releasing factor in pituitary stalk plasma from long-term ovariectomized rats: effects of steroids. Journal of Endocrinology 86 511-524.

Scully KM, Gleiberman AS, Lindzey J, Lubahn DB, Korach KS \& Rosenfeld MG 1997 Role of estrogen receptor $\alpha$ in the anterior pituitary gland. Molecular Endocrinology 11 674-681.

Shughrue PJ, Lane MV \& Merchenthaler I 1997a Comparative distribution of estrogen receptor- $\alpha$ and $-\beta$ mRNA in the rat central nervous system. Journal of Comparative Neurology 388 507-525.

Shughrue PJ, Lubahn DB, Negro-Vilar A, Korach KS \& Merchenthaler I $1997 b$ Responses in the brain of estrogen receptor $\boldsymbol{\alpha}$-disrupted mice. PNAS 94 11008-11012.

Shupnik MA 1996 Gonadotropin gene modulation by steroids and gonadotropin-releasing hormone. Biology of Reproduction 54 279-286.

Shupnik MA, Gharib SD \& Chin WW 1989a Divergent effects of estradiol on gonadotropin gene transcription in pituitary fragments. Molecular Endocrinology 3 474-480.

Shupnik MA, Weinmann CM, Notides AC \& Chin WW 1989b An upstream region of the rat luteinizing hormone beta gene binds estrogen receptor and confers estrogen responsiveness. Journal of Biological Chemistry 264 80-86.
Skynner MJ, Sim JA \& Herbison AE 1999 Detection of estrogen receptor alpha and beta messenger ribonucleic acids in adult gonadotropin-releasing hormone neurons. Endocrinology 140 5195-5201.

Tremblay GB, Tremblay A, Copeland NG, Gilbert DJ, Jenkins NA, Labrie F \& Giguere V 1997 Cloning, chromosomal localization, and functional analysis of the murine estrogen receptor beta. Molecular Endocrinology 11 353-365.

Turgeon JL, Kimura Y, Waring DW \& Mellon PL 1996 Steroid and pulsatile gonadotropin-releasing hormone $(\mathrm{GnRH})$ regulation of luteinizing hormone and GnRH receptor in a novel gonadotrope cell line. Molecular Endocrinology 10 439-450.

Vale W, Bilezikjian LM \& Rivier C 1994 Reproductive and other roles of inhibins and activins. In The Physiology of Reproduction, 2nd edn, pp 1861-1878. Eds E Knobil \& J D Neill. New York: Raven Press, Ltd.

Weick RF \& Noh KA 1984 Inhibitory effects of estrogen and progesterone on several parameters of pulsatile LH release in the ovariectomized rat. Neuroendocrinology 38 351-356.

Wersinger SR, Haisenleder DJ, Lubahn DB \& Rissman EF 1999 Steroid feedback on gonadotropin release and pituitary gonadotropin subunit mRNA in mice lacking a functional estrogen receptor alpha. Endocrine 11 137-143.

Wetsel WC, Hill DF \& Ojeda SR 1996 Basic fibroblast growth factor regulates the conversion of pro-luteinizing hormone-releasing hormone (ProLHRH) to LHRH in immortalized hypothalamic neurons. Endocrinology 137 2606-2616.

Wilson ME, Price RH Jr \& Handa RJ 1998 Estrogen receptor-b messenger ribonucleic acid expression in the pituitary gland. Endocrinology 139 5151-5156.

Wise PM \& Ratner A 1980 Effect of ovariectomy on plasma LH, FSH, estradiol, and progesterone and medial basal hypothalamic LHRH concentrations in old and young rats. Neuroendocrinology $3015-19$.

Wise PM, Camp-Grossman P \& Barraclough CA 1981a Effects of estradiol and progesterone on plasma gonadotropins, prolactin, and LHRH in specific brain areas of ovariectomized rats. Biology of Reproduction 24 820-830.

Wise PM, Rance N, Selmanoff M \& Barraclough CA $1981 b$ Changes in radioimmunoassayable luteinizing hormone-releasing hormone in discrete brain areas of the rat at various times on proestrus, diestrous day 1 , and after phenobarbital administration. Endocrinology 108 2179-2185.

Woodruff TK \& Mather JP 1995 Inhibin, activin and the female reproductive axis. Annual Review of Physiology 57 219-244.

Zoeller RT \& Young WS III 1988 Changes in cellular levels of messenger ribonucleic acid encoding gonadotropin-releasing hormone in the anterior hypothalamus of female rats during the estrous cycle. Endocrinology 123 1688-1689.

Zoeller RT, Seeburg PH \& Young WS III 1988 In situ hybridization histochemistry for messenger ribonucleic acid (mRNA) encoding gonadotropin-releasing hormone $(\mathrm{GnRH})$ : effect of estrogen on cellular levels of GnRH mRNA in female rat brain. Endocrinology 122 2570-2577.

Received 17 May 2006

Received in final form 13 July 2006

Accepted 17 July 2006

Made available online as an Accepted Preprint 8 August 2006 